\title{
Controlling in Tourism Companies - a Possible Way from the Pandemic
}

\section{Peter GALLO1', Daniela MATUŠíKOVÁ², Kristína ŠAMBRONSKÁ ${ }^{\star}$, Tomáš MOLČÁK ${ }^{4}$, Anna ŠENKOVÁ 5}

\author{
${ }^{1}$ Associate professor, University of Prešov in Prešov, Faculty of Management, Department of Tourism and Hotel \\ Management, Konštantínova 16, Prešov, Slovakia. \\ ${ }^{2,3,5}$ Senior lecturer, University of Prešov in Prešov, Faculty of Management, Department of Tourism and Hotel \\ Management, Konštantínova 16, Prešov, Slovakia. \\ ${ }^{4} \mathrm{PhD}$. Student, University of Prešov in Prešov, Faculty of Management, Department of Tourism and Hotel Management, \\ Konštantínova 16, Prešov, Slovakia. \\ E-mail: peter.gallo@unipo.sk¹, daniela.matusikova@unipo.sk², kristina.sambronska@unipo.sk², \\ tomas.molcak@smail.unipo.sk ${ }^{4}$, anna.senkova@unipo.sk ${ }^{5}$ \\ * Corresponding Author
}

\begin{abstract}
Received: 06.08.2021 Accepted: 19.10.2021 $\quad$ Published: 04.12.2021 $\quad$ DOI: 10.47750/QAS/22.185.10
\end{abstract}
\begin{abstract}
The research's aim was to verify the readiness of companies in the field of tourism for the changes caused by the pandemic Covid-19. Controlling is one of the most important tools of modern management, which could effectively solve the given problem. We consider the readiness of companies in this regard to be very important. The paper deals with the issue of using controlling in the management of tourism companies that currently try to survive in the time of strong influence of Covid-19 pandemics. The analysis of the current situation in companies was created on the basis of a questionnaire survey. Based on the research and subsequently tested assumptions, we tried to identify the strength of management of these companies in the context of their development in the post-pandemic period. It was confirmed that the implementation of controlling is related to the type and legal form of the tourism company. It was confirmed that the controlling subsystems must be applied with regard to the activities performed by the tourism company. The given recommendations and procedures may help to improve and to use controlling in the field of tourism more effectively in the post-pandemic period.
\end{abstract}

Keywords: controlling, management, tourism, entrepreneurs, pandemic Covid-19

\section{Introduction}

Management is currently a relatively well developed science and it has been applied in all sectors of the economy. Controlling originally emerged as part of management from the control function. Gradually, however, its concept has been refined and given new dimensions. At its core, management is management as planning, organizing, leading and controlling to achieve results with people (Kaehler 2019). However, when his conception is exposed to critical thinking, it seems to be unsatisfying. It is not only very vague and provides information on how management is actually practiced, but it also has some obvious shortcomings, such as its redundancy in managing people (i.e. human resource management). "Thus characterized, management is a universal human activity in domestic, social and political settings as well as in organizations. In fact, the term manage is widely used in everyday language and even in the organizational world. In a sense, the term refers to managers, i.e. people responsible for management. In a functional sense, it refers to the practice of management" (Boddy, 2017).

Controlling can be seen as one of the functions of management in the first stages. Controlling defines the processes that lead the team to the goals and monitors the performance of the goals (Bateman \& Snell, 2013). The purpose of controlling is to ensure that the organization is progressing towards the set goals. The controlling function of management is therefore very much linked to the planning phase. Within the tourism industry, the knowledge of controlling can be used in a very effective and purposeful way to solve the problems of the day.

Tourism is an important industry in the economy that optimizes the industrial structure. In times of pandemic crisis, tourism must play a role of responsibility as an integral part of society (Sambronská, 2020). One of the ways to check the readiness of companies in the field of tourism for the changes caused by the pandemic is also controlling, which can be considered as one of the methods of management towards success. Many foreign authors pay attention to the pandemic and its influence on business management, production management as well as services in tourism (Draghici, 2020; Sambronská 2020), while emphasizing the importance of transforming people's leadership and the need for controlling as an effective tool for measuring the differences between plan and reality (Boddy 2017). According to Pisar \& Kupec (2019), controlling ensures the successful and timely identification of possible deviations from the plan and their elimination by management. As stated by Levitska et al. (2020), controlling represents the actual measurement of performance and the evaluation of the difference between this plan and the actual performance. This also applies to the field of tourism. As state Stríteská \& Zapletal (2016), increasing globalization, integration and the technological revolution are 
the main challenges for maintaining the competitiveness and performance of today's businesses. Cabinova \& Onuferová (2019) say, controlling can be considered one of the management methods to succeed. One of the reasons why this is the case is the precise methodology and processes within the controlling systems (Marík et al. 2018). According to Gallo (2020), the modern definition of controlling can be defined as a management tool for success based on goals, plans, reality monitoring and finding deviations with the process of their solution.

\section{Theoretical background}

The current changes in turbulent environment require new approaches to business (Stefko, Rajnoha \& Lesnikova, 2019). Controlling represents an integrated information system of a company, the aim of which is to provide comprehensive information for economic-strategic management by comparing the planned indicators with the actual ones and evaluating of the resulting deviations (Craninckx \& Huyghebaert, 2015). An integrant part of controlling is also the elaboration of comprehensive technical and economic plans and monitoring of development trends of selected indicators for the needs of all levels of management - centres, operations, sections and senior management, including business owners. Controlling must therefore lead to process management that keeps the processes within the desired limits and ensures the achievement of predetermined results, not only financial, but also business, development, technical and others (Kaehler 2019). Controlling is a systematic transformation into the future of the business of goal-oriented activities (using a narrow set of management tools focused on bottlenecks) Hedija \& Fiala (2019).

According to the World Trade Organization (WTO), tourism can be defined as a temporary change of residence for the purpose of developing, getting to know and meeting people, leisure and recreation, which participants do in their free time and the length of stay does not exceed one year (Błazejovski, Kwiatkowski \& Gazda, 2019). Before pandemic period tourism was one of the strategic development sectors (Sugandini, Effendi, Susilo, Suryani, Muafi \& Syafri, 2019). It is an important sector of the economy that optimizes the industrial structure and can become an important element of sustainable economic development policy (Błazejovski, Kwiatkowski \& Gazda, 2019). The growing competitive environment forces companies in the field of tourism to react flexibly to rapidly changing economic conditions and to regularly monitor and evaluate the level of performance achieved (Sofranková, Horváthová, Kiseláková \& Matková, 2017). Bacík, Mudrík \& Stefko (2016) emphasize the need to monitor ever-changing trends in travel. In actual post pandemic time we can see the importance of economic and management processes in this sector and the need to use controlling in them. However, is it really so? The use of controlling in small as well as large tourism companies is currently an accepted and implemented tool for managing these companies. Controlling is used within tourism companies to analyse the internal processes and external environment of the company. Currently it is primarily used to reveal the reserve or measure the future effects of the implemented systems in place (Hedija \& Fiala, 2019) as well as measures to achieve the goal of minimizing the wage and financial costs of the strategic objectives of tourism entrepreneurs (Kiseláková \& Sofranková, 2017). As the controlling principle of the company in current times can be considered:

- performance targets characterized mainly by Key Performance Indicator (KPIs),
- balanced goals in a system of financial, customer, process and learning growth perspectives,

- goals in the HR Scorecard system based on innovation and learning to grow (Hornungová 2017).

The so set goals (in this way) and the controlling principle also apply in the tourism sector. Tourism should be again an important sustainable sector of the economy that optimizes the industrial structure and can become an important element of sustainable economic development policy (Sindleryová \& Lukác, 2017).

The effectiveness of the use of controlling is influenced by the classification of tourism and the systems of its division, which have an impact on its management systems. All these divisions subsequently characterize the expertise of the view and the process of researching events using controlling methods. The time aspect defines the intervals for examining the controlling processes and creating appropriate reporting (Gucík, Sebová \& Bajaník, 2015). From economics and tourism management point of view, we consider financial and economic criteria to be very important, namely liquidity, profitability and indebtedness (Jencová, 2014; Kiseláková \& Sofranková, 2017). All these divisions subsequently characterize the expertise of the view and the process of researching events using controlling methods. According to Błazejovski, Kwiatkowski \& Gazda, 2019, the time distribution of tourism can be considered as an important type criterion. The time aspect defines the intervals for examining the controlling processes and creating appropriate reporting. Tourism companies must constantly adapt to the everchanging motive and demand of tourism participants (Matusíková, 2019). The tourism company maintains its balance in the current extremely turbulent environment if it differentiates its own structure and creates diversity. The management of a tourism company must therefore enforce and follow rules, controls and plans. Strong competition in the tourism market requires not only the diversity of the offer but also its quality, which must be constantly monitored (Chodasová, 2017; Attila, 2016).

\section{Methodology and data}

The main aim of the research, was to analyse the state and use of controlling in the management of tourism companies, especially the hotel type. Based on the findings the aim was to propose measures for its innovation and increase the efficiency of use in the management process in the post pandemic period. We performed an analysis of the state of controlling based on a questionnaire, which was distributed electronically to selected tourism facilities. The research was conducted within 229 companies doing business in the field of tourism $(63 \%$ of companies were hotels, $19 \%$ guest houses and $18 \%$ other types of accommodation establishments doing business in the field of tourism, in concrete motels, private homes, tourist hostels and apartment houses). Data collection lasted from September 2020 to December 2020. We followed mainly the SK-NACE 55100 classification meaning revised classification of economic activities SK NACE Rev. 2 is fully harmonized with its European version NACE Revision 2 issued by Regulation of the European Parliament and of the Council no. 1893/2006. The use of this classification, resp. derived from the national version, is binding in the field of statistics for all Member States of the European Union (European parliament 2006). Statistical evaluation methods were verified at the significance level $\alpha=0.05$. To verify the hypotheses, we used the Chi-square test of good conformity (X2). We compiled hypotheses in the form of assumptions:

$\mathrm{H} 1$ : We assume that there is a statistical dependence 


\section{GENERAL MANAGEMENT}

between the type of Accommodation Company and the introduction of controlling in the company.

$\mathrm{H} 2$ : We assume that there is statistical significance depending on the legal form and the used controlling tools among tourism companies.

H3: We assume that the introduction of controlling improves the economic results of the tourism company.

The assumptions were verified and later recommendations for tourism companies were provided.

\section{Results and discussion}

\begin{tabular}{|l|l|l|l|}
\hline Chi-square $(\mathrm{CHI})$ & & & 10,032 \\
\hline Degree of variance & & & 6 \\
\hline Critical value for $\alpha=0,05$ (CHIkrit) & & & 12,59158724 \\
\hline If $\mathrm{CHI}<\mathrm{CHIkrit} \mathrm{hypothesis} \mathrm{is} \mathrm{accepted}$ & & & \\
\hline Result: & Hypothesis & accepted & \\
\hline $\mathrm{p}$ - value $=0,28$ how to count & & & 0,12 \\
\hline
\end{tabular}

Table 1: H1 hypothesis testing and result interpretation

\section{Source: own processing}

The most common answer for hotel establishments was that they have partially implemented controlling $(n=52)$. In the case of "guest house" type operations, it was the same share $(n=16)$ of the answers to the partial introduction of controlling and they are not aware that they have controlling in the company in the true sense of the word. From frequency Table 1 can be seen that the testing of hypothesis $\mathrm{H} 1$ shows that the calculated value of $\mathrm{X} 2=10.03$ is less than the critical value for the significance level $\alpha$ at 6 degrees of variance $X 2(6)=12.59$ and the calculated $p$-value $=0.12$. We accept hypothesis $\mathrm{H} 1$ and state that: "there is dependence between the type of Accommodation Company and the introduction of controlling in it".

\section{Evaluation of the hypothesis $\mathrm{H} 2$.}

We assume that there is statistical significance among tourism companies depending on the legal form and the used controlling tools. In this assumption, we started from the idea of which tools they use in business management in general

\section{Evaluation of the hypothesis $\mathrm{H} 1$.}

Within this hypothesis, we examined our assumption that there is a statistical dependence between the type of equipment and the introduction of controlling in the company. This means that we were interested in the fact whether hotels and guesthouses in particular know and have introduced controlling. We included facilities such as motels, private homes, tourist hostels and apartment houses in the other category. To verify the hypothesis, we used the Chi-square hypothesis testing method. The results were as follows - Table 1 .

and what leads them to do so.

The results show that business companies types s.r.o. and a.s. most often use managerial accounting in business management $(n=76)$. For entrepreneurs with a trade, managerial accounting also predominates. However, calculations and budgets are also often used. The results of the chi-square test shown show that the calculated value of $x^{2}$ $=12.55$ is less than the critical value for the significance level $\alpha$ at 8 degrees of variance $x 2(8)=15.51$ and the calculated $p$ value $=0,13$ is greater than the significance level $\alpha=0.05$ We also accept hypothesis $\mathrm{H} 2$ and state that: "There is statistical significance between tourism companies depending on the legal form and control tools used."

\section{Evaluation of the hypothesis $\mathrm{H} 3$.}

We assumed that accommodation companies use management tools to improve the economic result and cost management. The results of the $\mathrm{H} 3$ hypothesis test are in Table2.

\begin{tabular}{|l|l|l|l|l|}
\hline Chi-square $(\mathrm{CHI})$ & & & & 7,698 \\
\hline Degree of variance & & & & 24 \\
\hline Critical value for $\alpha=0,05$ (CHIkrit) & & & & 36,415 \\
\hline If $\mathrm{CHI}<\mathrm{CHIkrit}$ hypothesis is accepted & & & & \\
\hline Results: & & & Hypothesis & accepted \\
\hline$p$ - value $=0,91$ how to count & & & & 0,999339 \\
\hline
\end{tabular}

Table 2. H3 hypothesis testing and result interpretation

\section{Source: own processing}

Testing of hypothesis $\mathrm{H} 3$ by the chi-square test shown in Table 2 shows that the calculated value of $x 2=7.698$ is greater than the critical value for the significance level $\alpha$ at 32 degrees of freedom $\times 2(32)=36.415$ and the calculated $p$ value $=0.999$ is greater as the set significance level $\alpha=0.05$, so we accept the null hypothesis H3. Based on hypothesis, we accept hypothesis $\mathrm{H} 3$ and state that "introduction of controlling improves the economic results of the accommodation company".

Based on hypothesis, we can state that controlling is an excellent tool for solving poor economic results and significantly affects the economic results of the company. Implementation of controlling in tourism companies can be implemented in two stages:

1. Introduction of a strategic controlling system and evaluation of the tourism company performance.

2. Introduction of a financial and cost controlling system for effective management of economic results.

Acceptance of a controlling system into a company is not an easy process. It is important to proceed with caution when 


\section{GENERAL MANAGEMENT}

implementing it. The sequence of steps must be followed. The system can be accepted into the company partially - only some parts or the whole.

1. Implementing controlling into practice involves several important steps:

2. Defining controlling in a company.

3. Competence and responsibilities of controlling, its competencies.

4. System and organization of strategic controlling tasks.

5. System of organizing tasks of cost and financial controlling.

6. The structure of introducing the concept of controlling into the company.

7. Fulfilment of the controlling implementation plan.

The initial information for starting work the system uses from general ledger of the company, reporting, subsequent sales, human resources and marketing data and others. The outputs are processed in a managerial form in the form of reporting, which the department submits to superiors. An important output of the work for this department is the transfer of data from accounting to a form that is as easy to process and easy to read for managers, which will always have the necessary data at hand at any time in the form of dashboards.

Figure 1 shows the design of a model for solving economic results in the after pandemic period. The model allows managers to make effective proposals and decisions and automatically interpret and predict the results of the decision in the future. The basic indicators of business efficiency in tourism are economic value added, return on assets (ROA), total liquidity, indebtedness and profit. The figure also shows status and decision indicators in the form of KPI.
The dashboard presented in picture no. 1 shows a comprehensive financial situation of the company. The advantage of such a model is that it shows the development trend in the period of 2017-2024 (past and future period). The model shows a typical company affected by the pandemic situation and the way out of the crisis. It can be seen that despite the measures the Business Value is negative. This means that if companies want to get out of the crisis, it will take them several years to return to their original state. This is also indicated by the development trend of EVA, ROA, Total Liquidity and Total Indebtedness, where the results deteriorated in 2019-2021 as a result of a pandemic, and in the following years we already expect a positive development. Changes in individual indicators were developing very slowly. Particularly it concerned the Total Liquidity, where a typical company reached the permissible minimum liquidity limit of 11.2 in 2022. It will take up to an optimal value of 1.5-2 until 2024. Similarly, in 2020 it is possible to monitor high Total Indebtedness. It will reach the $70 \%$ threshold in 2024 . The profitability of ROA in the event of a drop in profitability may return to a positive level of $4 \%$ in 2022 . Similarly, it can be seen in other Key Performance Indicators, namely Business Value, Creditworthiness index, Z-score, IN01 Index, EBT / Revenues, Productivity, Degree of Undercapitalization, OEAT, WACC, ROCE and Cash Flow, where a positive trend will appear after 2022, as it is presented on the individual graphs of the model. Dashboard comprehensively shows what has happened and will happen to the company in the future with good management. It includes the typical behaviour of tourism companies affected by the pandemic crisis.

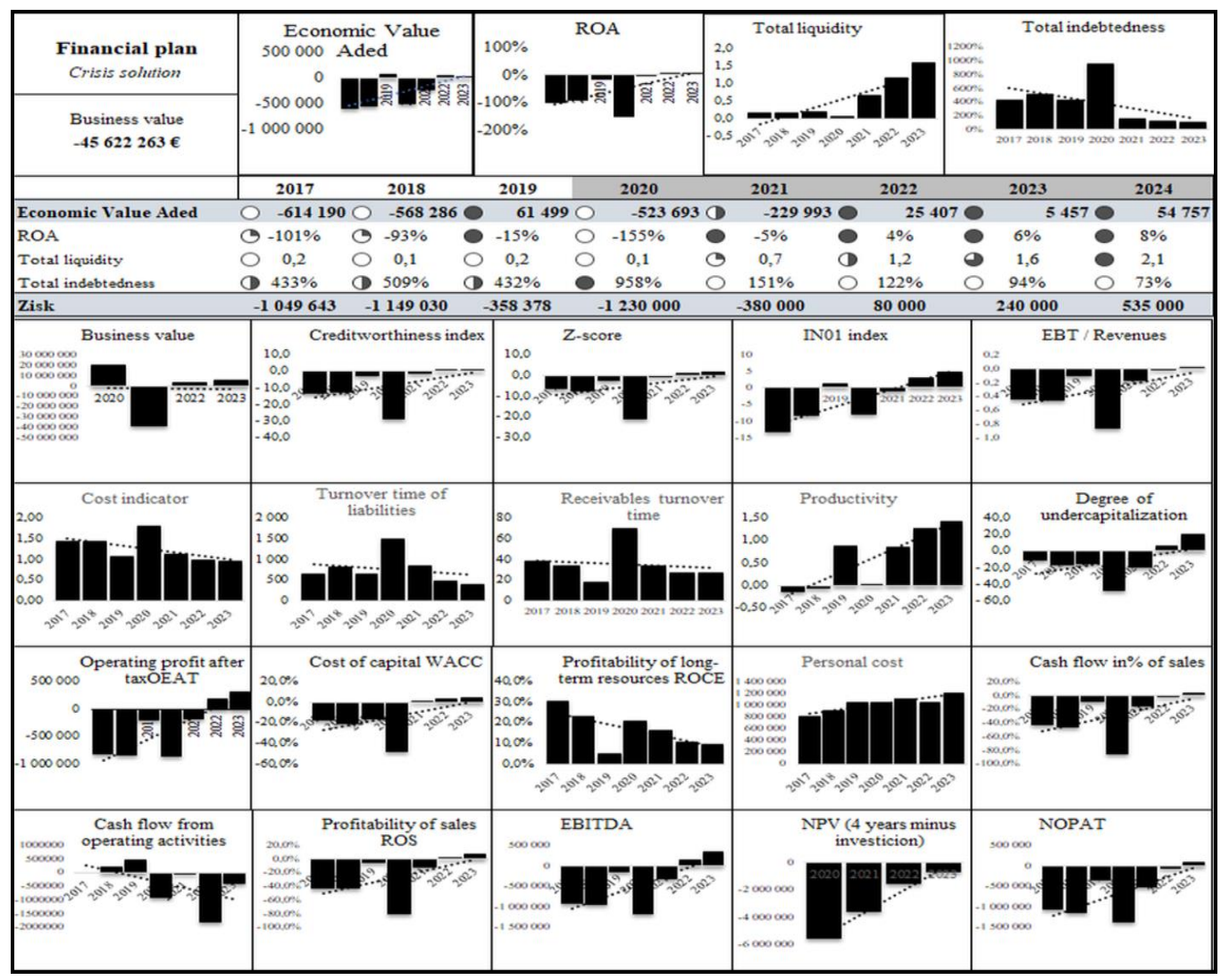

Figure 1: Model solving of economic results and the decisions' impact

Source: own processing 


\section{GENERAL MANAGEMENT}

\section{Conclusion}

Based on presented results, we can conclude that controlling is an important part of the management of tourism companies. It can significantly improve economic results, which in today's post-pandemic period can play an important role in the system of future development of the national economy. Given the current situation, taking into account the crisis caused by the pandemic, we propose a control solution with partial use of elements of artificial intelligence and managerial skills to predict the future results of businesses in tourism. Proper implementation and setting of control parameters in tourism companies can lead to increased employee satisfaction, process optimization, increased customer satisfaction and financial stability of the company.

\section{References}

[1] Attila, A. T. (2016). The Impact of the Hotel Industry on the Competitiveness of Tourism Destinations in Hungary. Journal of Competitiveness, 8(4), 85-104. doi:10.7441/joc.2016.04.06

[2] Bacík, R., Múdrik, M., Stefko, R. (2016). Analysis of tourism travel trends after 2014. In Journal of Environmental Management and Tourism. Vol. 7, No. 1, pp. 88-93.

[3] Bateman, T., Snell, S. (2013). Management. McGraw Hill / Irwin: New York.

[4] Błażejowski, M., Kwiatkowski, J., \& Gazda, J. (2019). Sources of Economic Growth: A Global Perspective. Sustainability, 11(1), 275. doi:10.3390/su11010275

[5] Boddy, D. (2017). Management - An Introduction (7th edition). Harlow: Pearson Education, ISBN 978-1-292-08859-4, 978-1292-08862-4, pp.7-8.

[6] Craninckx, K., \& Huyghebaert, N. (2015). Large shareholders and value creation through corporate acquisitions in Europe. The identity of the controlling shareholder matters. European Management Journal, 33(2), 116-131. doi:10.1016/j.emj.2014.09.001

[7] Cabinova, V., Onuferová, E. (2019). Efficiency and financial performance evaluation of the medical spa sector: An empirical study from Slovakia. In Quality - Access to Success: journal of management system. Vol. 20, No. 172, pp. 62-68.

[8] Draghici, A. (2020). Changes and challenges of human systems management during and after the pandemic. Human Systems Management, 39(4), 469-472. doi:10.3233/hsm209001

[9] European parliament. (2006). Regulation (EC) 1893/2006 of the European Parliament and of the Council of 20 December 2006 establishing the statistical classification of economic activities NACE Revision 2 and amending Council Regulation (EEC) No $3037 / 90$ as well as certain EC Regulations on specific statistical domains European parliament. (2006). Regulation (EC) 1893/2006 of the European Parliament and of the Council of 20 December 2006 establishing the statistical classification of economic activities NACE Revision 2 and amending Council Regulation (EEC) No $3037 / 90$ as well as certain EC Regulations on specific statistical domains

[10] Gallo, P. (2020). Digitálny manažment. Dominanta, Prešov

[11] Gucík, M., Sebová, L., Bajaník, T. (2015) Kontroling podnikov cestovného ruchu. Wolters Kluwer, Bratislava

[12] Hedija, V., \& Fiala, R. (2019). Is Gibrat's law valid for travel agencies and tour operators? Evidence from the Visegrad group countries. Journal of East European Management Studies, 24(3), 447-465. doi:10.5771/0949-6181-2019-3-447
[13] Hornungová, J. (2017). NONFINANCIAL PERFORMANCE EVALUATION AS SIGNIFICANT AREA OF STRATEGIC BUSINESS MANAGEMENT. Business: Theory and Practice, 18(0), 71-78. doi:10.3846/btp.2017.008

[14] Chodasová, Z. (2012). Podnikový controlling nástroj manažmentu. STATIS, Bratislava

[15] Jencová, S. (2014). Finančno-ekonomická analýza podnikatel'ských subjektov. Bookman, s. r. o., Prešov

[16] Kaehler, B., Grundei, J. (2019). HR Governance. A Theoretical Introduction. Springer International Publishing. ISBN 978-3319-94526-2, DOI 10.1007/978-3-319-94526-2, pp.11.

[17] Kiseláková, D., Sofranková, B. (2017). Moderný finančný manažment podnikatel'ských subjektov. Bookman, s.r.o. Prešov

[18] Levytska, S., Akimova, L., Zaiachkivska, O., Karpa, M., \& Gupta, S. K. (2020). MODERN ANALYTICAL INSTRUMENTS FOR CONTROLLING THE ENTERPRISE FINANCIAL PERFORMANCE. Financial and Credit Activity: Problems of Theory and Practice, 2(33), 314-323. doi:10.18371/fcaptp.v2i33.206967

[19] Lloyd, R., Aho. W. (2020). The Four Functions of Management. Essential Guide to Management Principles. Hays, Kansas, Digital Pressbooks,FHSU Digital Press, pp 153.

[20] Marík, M, et al. (2018). Metody oceňování podniku pro pokročilé: Hlubší pohled na vybrané problémy. Ekopress, Praha

[21] Matusíková, D. (2019). Úvod do terminológie cestovného ruchu pre manažérov: Učebnica pre predmet Základy cestovného ruchu. Bookman, Prešov

[22] Písař, P., \& Kupec, V. (2019). Innovative controlling and audit opportunities for SMEs. Problems and Perspectives in Management, 17(3), 184-195 doi:10.21511/ppm.17(3).2019.15

[23] Stríteská, M., Zapletal, D., \& Jelínková, L. (2016). Performance management systems in Czech companies: findings from a questionnaire survey. E+M Ekonomie a Management, 19(4), 44-55. doi:10.15240/tul/001/2016-4-004

[24] Sugandini, D., Effendi, M. I., Susilo, P., Suryani, W., Muafi \& Syafri, W. (2019). Revisit Intention: The Study of Community Based Tourism. In Quality-Access to Success. Vol. 20, No. 173. pp. 100-106.

[25] Sambronská K. (2020). Podpora turizmu vo vybraných krajinách vzhl'adom na pandémiu Covid-19. In Mladá veda. [Young Science].Vol. 8, No. 1, pp. 222-230.

[26] Sindleryová, I., Lukác, I. (2017). Marketing management integration within the praxis of regional cultury policy. In Current Trends and Public Administration, conference proceedings. Uherské Hradište: Faculty of adminsitration and economic studies. pp. 85-102.

[27] Sofranková, B., Horváthová, J., Kiseláková, D., Matková, S (2017). Analytical view on performance evaluation of service enterprises. In European financial systems 2017: Proceedings of the 14th international scientific conference: part 2. pp. 287294.

[28] Stefko, R., Rajnoha, R., Lesnikova, P., et al. (2019). Transformations in strategic business planning in the context of sustainability and business goals setting. In Transformations in business \& Economics. Vol. 18, No. 2, pp. 44-66. 